\title{
NQ-Y15 Inhibits the Calcium Mobilization by Elevation of Cyclic AMP in Rat Platelets
}

\author{
Tong-Shin Chang, ${ }^{a}$ Ki-Seon Lee, ${ }^{a}$ Gwi-Yeop Lee, ${ }^{a}$ Sun-Duck Jeon, ${ }^{a}$ Dhong-Su So, ${ }^{a}$ Lee-Yong KhIL, ${ }^{a}$ \\ Myung-Kiu Chung, ${ }^{b}$ and Chang-Kiu Moon*,a \\ College of Pharmacy, Seoul National University, ${ }^{a}$ San 56-1 Shillim-Dong, Kwanak-Gu, Seoul 151-742, Korea and \\ Department of Environmental Engineering, Sunmoon University, ${ }^{b}$ Asan-Si, Chung-Nam, 336-840, Korea. \\ Received September 7, 2000; accepted February 6, 2001
}

2-[(4-Cyanophenyl)amino]-3-chloro-1,4-naphthalenedione (NQ-Y15) is a dual action drug which acts as a thromboxane $\mathrm{A}_{2}\left(\mathrm{TXA}_{2}\right)$ synthase inhibitor and $\mathrm{TXA}_{2} / \mathrm{PGH}_{2}$ receptor antagonist. In the present study, we examined the effects of $\mathrm{NQ}-\mathrm{Y} 15$ on $\mathrm{Ca}^{2+}$ mobilization, which is the common event in various types of platelet activation, in arachidonic acid (AA)-stimulated rat platelets. The elevation of cytosolic $\mathrm{Ca}^{2+}$ concentration $\left(\left[\mathrm{Ca}^{2+}\right]_{\mathrm{i}}\right)$ induced by AA was inhibited by NQ-Y15 in a concentration-dependent manner. This inhibition-effect of NQ-Y15 was found to be based on the suppression of the rise in $\left[\mathrm{Ca}^{2+}\right]_{i}$ by the inhibition of both $\mathrm{Ca}^{2+}$ release from internal stores and $\mathrm{Ca}^{2+}$ influx from the extracellular space. Our successive trial was focused on the role of cyclic AMP (cAMP) in the action of NQ-Y15, because cAMP was reported to be increased by dual action drugs such as picotamide and to inhibit the increase in $\left[\mathrm{Ca}^{2+}\right]_{\mathrm{i}}$. NQ-Y15 was confirmed to increase cAMP in AA-stimulated rat platelets. These results suggested that NQ-Y15 might inhibit the rise in $\left[\mathrm{Ca}^{2+}\right]_{\mathrm{i}}$ in AA-treated rat platelets by increasing cAMP, which is involved in the inhibition of platelet activation.

Key words 2-[(4-cyanophenyl)amino]-3-chloro-1,4-naphthalenedione; platelet; calcium mobilization; cyclic AMP

Thromboxane $\mathrm{A}_{2}\left(\mathrm{TXA}_{2}\right)$ is a powerful platelet agonist and its formation in stimulated platelets represents an important amplifying signal for platelet activation. ${ }^{1)} \mathrm{TXA}_{2}$ exerts its effects on platelets by binding to $\mathrm{TXA}_{2} / \mathrm{PGH}_{2}$ (prostaglandin $\mathrm{H}_{2}$ ) receptors, ${ }^{2}$ ) followed by the activation of both phospholipase C (PLC) and protein kinase C (PKC), leading to an increase in cytosolic $\mathrm{Ca}^{2+}$ concentration $\left(\left[\mathrm{Ca}^{2+}\right]_{\mathrm{i}}\right),{ }^{3,4)}$ Cytosolic $\mathrm{Ca}^{2+}$ plays important roles in the regulation of various physiological functions, including aggregation and granule secretion of platelets. ${ }^{5)}$

The inhibition of $\mathrm{TXA}_{2}$ synthase alone cannot fully suppress the platelet activation because $\mathrm{PGH}_{2}$ could be accumulated due to $\mathrm{TXA}_{2}$ synthase inhibition and could act as a potent platelet stimulant by interacting with the platelet $\mathrm{TXA}_{2} /$ $\mathrm{PGH}_{2}$ receptors. ${ }^{6,7)}$ Thus, it has been suggested that the TXA synthase inhibitors and $\mathrm{TXA}_{2} / \mathrm{PGH}_{2}$ receptor antagonists may provide an antiplatelet regimen superior to those previ-

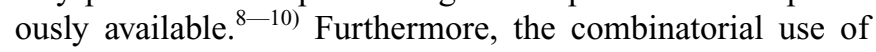
$\mathrm{TXA}_{2}$ synthase inhibitor and $\mathrm{TXA}_{2} / \mathrm{PGH}_{2}$ receptor antagonist deserves particular interest, because this can lead to the increase in $\mathrm{CAMP}^{9,10)}$ which serves as a second messenger to inhibit the increase in $\left[\mathrm{Ca}^{2+}\right]_{\mathrm{i}}$ in activated platelets. ${ }^{11,12)} \mathrm{An}$ increased cAMP was observed in platelets only when arachidonic acid (AA)-stimulated platelets were pretreated with $\mathrm{TXA}_{2}$ synthase inhibitor and $\mathrm{TXA}_{2} / \mathrm{PGH}_{2}$ receptor antagonist simultaneously; this increase, however, did not occur in platelets preincubated with only one of those two agents or in unstimulated platelets. ${ }^{910)}$

Some drugs that act as both $\mathrm{TXA}_{2}$ synthase inhibitors and $\mathrm{TXA}_{2} / \mathrm{PGH}_{2}$ receptor antagonists, also increased intraplatelet cAMP in AA-stimulated platelets. ${ }^{13,14)}$ 2-[(4-Cyanophenyl)amino]-3-chloro-1,4-naphthalenedione (NQ-Y15) exerts dual action as a $\mathrm{TXA}_{2}$ synthase inhibitor and a $\mathrm{TXA}_{2} / \mathrm{PGH}_{2}$ receptor antagonist in rat platelets, as previously reported. ${ }^{15)} \mathrm{In}$ the present study, we investigated whether NQ-Y15 increases cAMP in AA-stimulated platelets, leading to the inhibition of
$\mathrm{Ca}^{2+}$ mobilization.

\section{MATERIALS AND METHODS}

Materials NQ-Y15 was synthesized and characterized as described previously. ${ }^{16)}$ It was dissolved in dimethyl sulfoxide (DMSO) so that the final DMSO concentration in reaction mixtures never exceeded $0.5 \%(\mathrm{v} / \mathrm{v})$. AA, bovine serum albumin (BSA), indomethacin, imidazole, DMSO, ethylene diamine tetraacetic acid (EDTA), ethylene glycolbis( $\beta$-aminoethyl ether)- $N, N, N^{\prime}, N^{\prime}$-tetraacetic acid (EGTA) and fura 2/AM were purchased from Sigma Chemical Co. (St. Louis, MO, U.S.A.). Picotamide was purchased from Biomol (Plymouth Meeting, PA, U.S.A.). Radioimmuno assay (RIA) kits of cAMP were obtained from Amersham (Little Chalfont, Buckinghamshire, England). All other reagents were purchased from Sigma Chemical Co.

Preparation of Platelets Rat blood was taken from Sprague-Dawley female rats weighing $200-250 \mathrm{~g}$. Rats were anesthetized with ethyl ether and blood was collected from the abdominal aorta and anticoagulated with sodium citrate $(3.8 \% ; 1: 9, \mathrm{v} / \mathrm{v})$. The blood was centrifuged at $120 \boldsymbol{g}$ for $15 \mathrm{~min}$. The supernatants were pooled and centrifuged at $600 \mathrm{~g}$ for $15 \mathrm{~min}$ at room temperature. The platelet pellets were washed with modified Tyrode-HEPES buffer $(129 \mathrm{~mm}$ $\mathrm{NaCl}, 2.8 \mathrm{~mm} \mathrm{KCl}, 8.9 \mathrm{~mm} \mathrm{NaHCO}, 0.8 \mathrm{~mm} \mathrm{MgCl}_{2}, 0.8 \mathrm{~mm}$ $\mathrm{KH}_{2} \mathrm{PO}_{4}, 2 \mathrm{~mm}$ EGTA, $5.6 \mathrm{~mm}$ glucose, $10 \mathrm{~mm}$ HEPES, $0.35 \%$ BSA, pH 7.4) and centrifuged at $600 \boldsymbol{g}$ for $15 \mathrm{~min}$. This washing procedure was repeated twice and platelets were then gently resuspended in Tyrode-HEPES buffer $\left(129 \mathrm{~mm} \mathrm{NaCl}, 2.8 \mathrm{~mm} \mathrm{KCl}, 8.9 \mathrm{~mm} \mathrm{NaHCO}_{3}, 0.8 \mathrm{~mm}\right.$ $\mathrm{MgCl}_{2}, 0.8 \mathrm{~mm} \mathrm{KH}_{2} \mathrm{PO}_{4}, 1 \mathrm{~mm} \mathrm{CaCl}, 5.6 \mathrm{~mm}$ glucose, $10 \mathrm{~mm}$ HEPES, $0.35 \%$ BSA, pH 7.4). Platelet counts were determined using a model ZM Coulter Counter (Coulter Electronics, Hialeah, FL, U.S.A.).

Determination of Intracellular $\mathrm{Ca}^{2+}$ in Platelets The 
$\left[\mathrm{Ca}^{2+}\right]_{\mathrm{i}}$ was determined in fura-2-loaded platelets using the method described by Pollock and Rink. ${ }^{17)}$ Briefly, platelets $\left(8 \times 10^{8} / \mathrm{ml}\right)$ were incubated with fura-2/AM $(3 \mu \mathrm{M})$ for $45 \mathrm{~min}$ at $37^{\circ} \mathrm{C}$ and then centrifuged for $15 \mathrm{~min}$ at $800 \boldsymbol{g}$; the resultant pellet was washed with EDTA (1 mM)-containing Tyrode-HEPES buffer. After centrifugation, platelets were gently resuspended to a concentration of $2 \times 10^{8} / \mathrm{ml}$ in $\mathrm{CaCl}_{2}$ free Tyrode-HEPES buffer and kept at room temperature. Fluorescence was measured at the emission wavelength of $505 \mathrm{~nm}$ with the excitation wavelength switched continuously between 340 and $380 \mathrm{~nm}$ using a Shimadzu RF-5000 spectrofluorimeter, which was equipped with the thermostated $\left(37^{\circ} \mathrm{C}\right)$ and magnetically stirred cuvette. The ratio of the fluorescence intensities at the two excitation wavelengths was used to determine $\left[\mathrm{Ca}^{2+}\right]_{\mathrm{i}}{ }^{18)}$ Intracellular $\mathrm{Ca}^{2+}$ concentration was determined by calibration of the fura- 2 signal. Platelets were lysed with $0.1 \%(\mathrm{v} / \mathrm{v})$ Triton X-100 to determine the maximum fluorescence; $10 \mathrm{~mm}$ EGTA ( $\mathrm{pH}$ 9.0) was added to determine the minimum fluorescence.

cAMP Assay Platelet suspension $\left(3 \times 10^{8} / \mathrm{ml}\right)$ was incubated with NQ-Y15 or its vehicle at $37^{\circ} \mathrm{C}$ for $8 \mathrm{~min}$ under shaking at $1200 \mathrm{rpm}$ with a Thermomixer ${ }^{\circledR}$ (EppendorfNetheler-Hinz GmbH, Hamburg, Germany), and then $50 \mu \mathrm{M}$ AA or an equal volume of saline was added. After 6 min-further incubation, the reaction was stopped by adding $10 \mathrm{~mm}$ EDTA followed immediately by boiling for $5 \mathrm{~min}$ as described by Karniguian et al. ${ }^{19)}$ Upon cooling to $4^{\circ} \mathrm{C}$, precipitated protein was sedimented by centrifugation in an Eppendorf microcentrifuge (model 5413). The supernatant was used to determine cAMP content by RIA.

Statistical Analysis Results are expressed as mean士 S.E.M. Statistical significance was assessed using the Student's $t$ test with $p<0.05$ or $p<0.01$.

\section{RESULTS}

Effects of NQ-Y15 on AA-Induced $\mathrm{Ca}^{2+}$ Release from Internal Stores As shown in Fig. 1A, platelets were incubated in the presence of $0.5 \mathrm{~mm}$ EGTA (that was the virtual absence of free $\mathrm{Ca}^{2+}$ in the incubation media) followed by the addition of $50 \mu \mathrm{m}$ AA. AA caused a prompt increase in
$\left[\mathrm{Ca}^{2+}\right]_{\mathrm{i}}$ from $61.5 \pm 3.2$ to $95.6 \pm 2.7 \mathrm{nM}(n=4)$. This increase reflected $\mathrm{Ca}^{2+}$ release from internal stores. ${ }^{20)}$ As shown in Fig. 1B, NQ-Y15 inhibited this $\mathrm{Ca}^{2+}$ release by $45.7 \%(n=4)$ at $30 \mu \mathrm{M}$.

Effects of NQ-Y15 on AA-Induced $\mathrm{Ca}^{2+}$ Influx To examine the effect of NQ-Y15 on $\mathrm{Ca}^{2+}$ influx, we measured the change in $\left[\mathrm{Ca}^{2+}\right]_{\mathrm{i}}$, excluding the increase in $\mathrm{Ca}^{2+}$ release from intracellular store. In platelets suspended in TyrodeHEPES buffer containing $0.5 \mathrm{~mm}$ EGTA, $50 \mu \mathrm{M}$ AA increased $\left[\mathrm{Ca}^{2+}\right]_{\mathrm{i}}$ from $62.8 \pm 4.7$ to $94.7 \pm 53.2 \mathrm{nM}(n=4)$ (Fig. $2 \mathrm{~A})$. This increase in $\left[\mathrm{Ca}^{2+}\right]_{\mathrm{i}}$ was caused by the release of $\mathrm{Ca}^{2+}$ from internal stores, which led to $\mathrm{Ca}^{2+}$ depletion in internal stores. ${ }^{21)} 12$ minutes of stimulation with AA followed by the addition of $2 \mathrm{mM} \mathrm{Ca}{ }^{2+}$ increased $\left[\mathrm{Ca}^{2+}\right]_{\mathrm{i}}$ to $584.0 \pm$ $53.2 \mathrm{~nm}(n=4)$, which represented $\mathrm{Ca}^{2+}$ influx (Fig. 2A). This $\mathrm{Ca}^{2+}$ influx was substantially (by $79.9 \%$ ) reduced by $30 \mu \mathrm{M}$ NQ-Y15 (Fig. 2B).

Effect of NQ-Y15 on cAMP Level in AA-Stimulated Platelets The level of cAMP was found to be very low in resting platelets $\left(6.4 \pm 0.2 \mathrm{pmol} / 3 \times 10^{8}\right.$ platelets $)$. At the same condition, $80 \mu \mathrm{M} \mathrm{PGI}_{2}$, an adenylate cyclase activator, increased the cAMP level up to $51.0 \pm 1.1 \mathrm{pmol} / 3 \times 10^{8}$. The

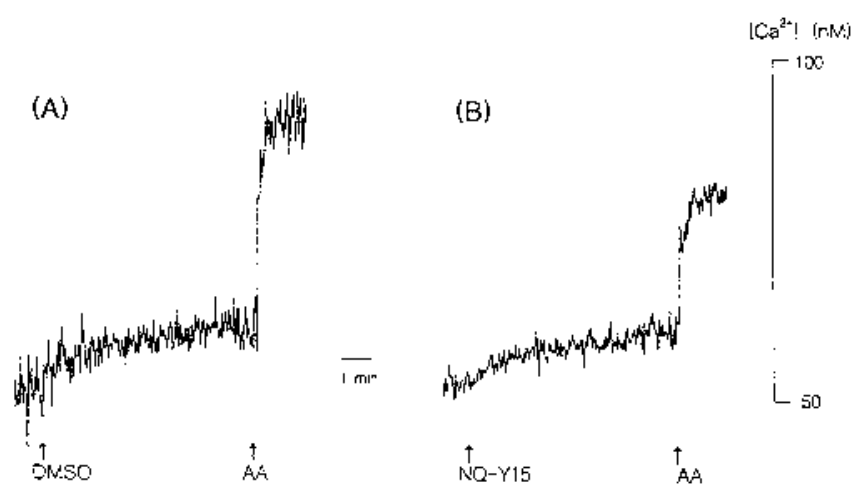

Fig. 1. Effect of NQ-Y15 on AA-Induced $\mathrm{Ca}^{2+}$ Release from Internal Stores in Fura-2-Loaded Platelets

To determine $\mathrm{Ca}^{2+}$ release from internal stores, we used fura-2-loaded platelets suspended in Tyrode-HEPES buffer containing $0.5 \mathrm{~mm}$ EGTA, excluding the extracellular $\mathrm{Ca}^{2+}$. DMSO $(0.1 \%, \mathrm{~A})$ or NQ-Y15 $(30 \mu \mathrm{M}, \mathrm{B})$ was added to the reaction mixture at $8 \mathrm{~min}$ before AA $(50 \mu \mathrm{M})$ stimulation. Traces are representative of 4 experiments.

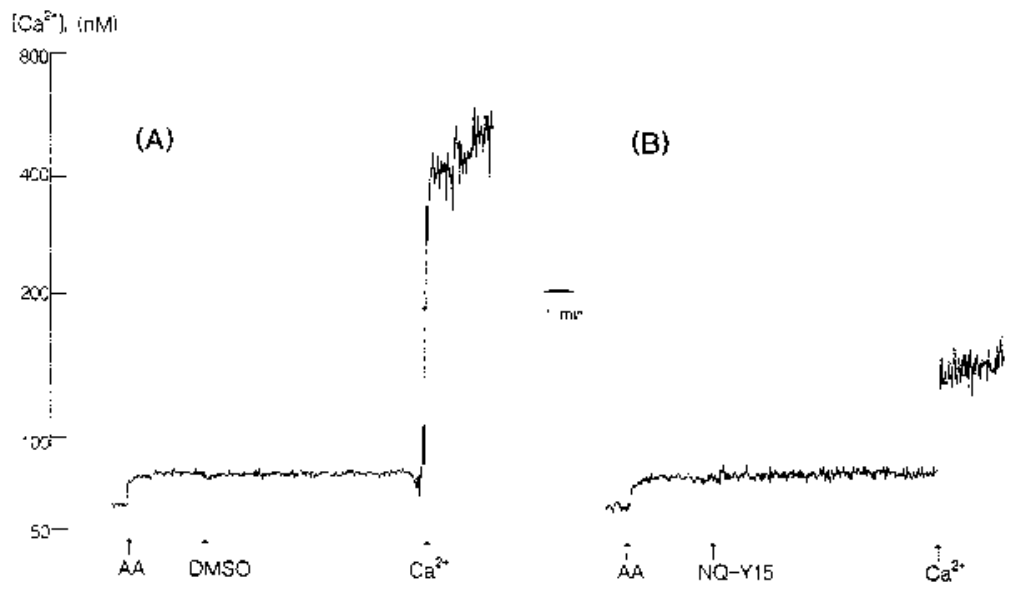

Fig. 2. Effect of NQ-Y15 on AA-Induced $\mathrm{Ca}^{2+}$ Influx in Fura-2-Loaded Platelets

$\mathrm{Ca}^{2+}$ depletion from internal stores was induced by AA $(50 \mu \mathrm{M})$ in the absence of external $\mathrm{Ca}^{2+}\left(0.5 \mathrm{~mm}\right.$ EGTA). $\mathrm{Ca}^{2+}$ influx from medium was induced by $\mathrm{Ca}^{2+}$ repletion to $2.0 \mathrm{mM} \mathrm{CaCl} l_{2}$, at $12 \mathrm{~min}$ after AA stimulation. DMSO $(0.1 \%)$ or NQ-Y15 $(30 \mu \mathrm{M})$ was added to the reaction mixture at 8 min before applying excess $\mathrm{Ca}^{2+}$. Traces are representative of 4 experiments. 

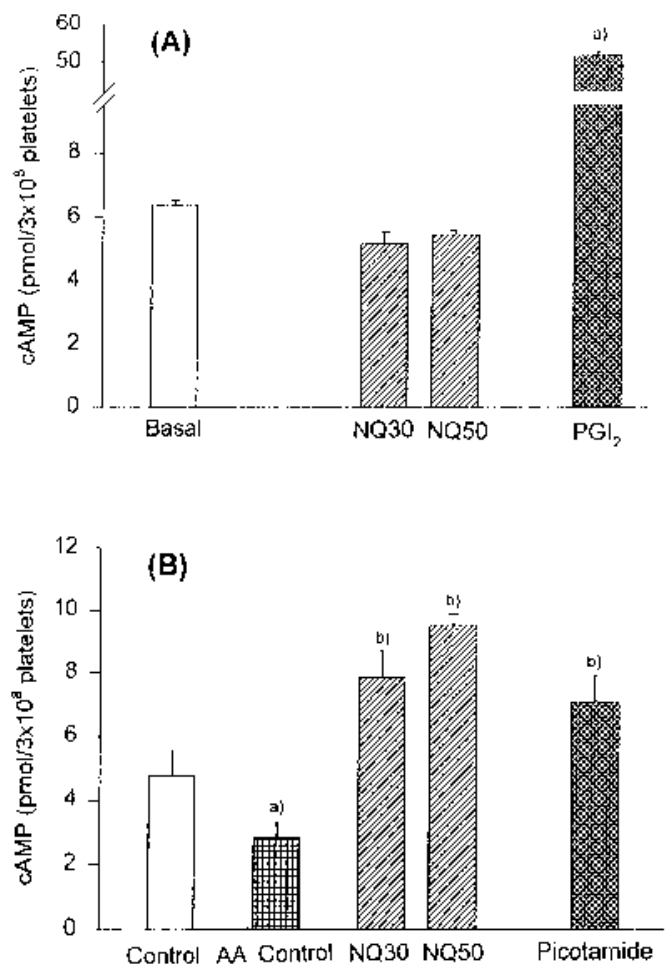

Fig. 3. Effect of NQ-Y15 on cAMP Levels in Unstimulated Platelets (A) and AA-Stimulated Platelets (B)

(A) cAMP formation was assayed at $8 \mathrm{~min}$ of incubation of platelets with DMSO (0.5\%, Basal), $30 \mu \mathrm{M}$ NQ-Y15 (NQ30), $50 \mu \mathrm{M}$ NQ-Y15 (NQ50) or $80 \mu \mathrm{M} \mathrm{PGI}_{2}\left(\mathrm{PGI}_{2}\right)$ at $37^{\circ} \mathrm{C}$. (B) $50 \mu \mathrm{M}$ AA was added to the reaction mixture $8 \mathrm{~min}$ after the addition of vehicle, NQ-Y15 or picotamide. Five minutes after the addition of AA, cAMP formation was stopped by adding $10 \mathrm{~mm}$ EDTA and immediately boiling for $5 \mathrm{~min}$. Values are means \pm S.E.M. $(n=5)$. Key: $a) p<0.01$ as compared to basal; $b) p<0.01$ compared to AA. Control: platelet suspension + vehicle of NQ-Y15 (DMSO 0.5\%), AA control: control+AA $(50 \mu \mathrm{M})$, NQ30: platelet suspension+NQ-Y15 $(30 \mu \mathrm{M})+\mathrm{AA}, \quad \mathrm{NQ50}$ : platelet suspension+NQ-Y15 $(50 \mu \mathrm{M})+\mathrm{AA}$, picotamide: platelet suspension+ picotamide $(1 \mathrm{~mm})+$ AA.

cAMP level was not affected by NQ-Y15 at 30 and $50 \mu \mathrm{M}$ in unstimulated platelets. This means that NQ-Y15 has no direct effect on adenylate cyclase. By the stimulation of platelets with $50 \mu \mathrm{M} \mathrm{AA}$, the level of cAMP was lowered to $2.9 \pm 0.2 \mathrm{pmol} / 3 \times 10^{8}$ platelets, which is about $60 \%$ of its level in resting platelets (Fig. 3B). This decrease was overcome by preincubation with picotamide, which has dual functions as a TXA 2 synthase inhibitor and a $\mathrm{TXA}_{2} / \mathrm{PGH}_{2}$ receptor antagonist. ${ }^{13)}$ As a consequence of the preincubation of AA stimulated platelets with $1 \mathrm{~mm}$ picotamide, the cAMP level rose to $7.1 \pm 0.4 \mathrm{pmol} / 3 \times 10^{8}$, which is higher than that in resting platelets. Likewise, NQ-Y15 (30 and $50 \mu \mathrm{M})$ caused significant elevation of the cAMP level in AA-stimulated platelets $\left(7.9 \pm 0.4\right.$ and $9.5 \pm 0.2 \mathrm{pmol} / 3 \times 10^{8}$, respectively).

\section{DISCUSSION}

Exogenous AA-induced aggregation, granule release and the rise in $\left[\mathrm{Ca}^{2+}\right]_{\mathrm{i}}$ of platelets are due to the formation of $\mathrm{TXA}_{2}{ }^{3}{ }^{3,4} \mathrm{AA}$ is metabolized to $\mathrm{TXA}_{2}$ via two enzymatic steps, including PGH synthesis and $\mathrm{TXA}_{2}$ synthesis. TXA exerts its effects on platelets by binding to the $\mathrm{TXA}_{2} / \mathrm{PGH}_{2}$ receptor. ${ }^{2)}$ In platelets, the stimulation of $\mathrm{TXA}_{2} / \mathrm{PGH}_{2}$ receptors leads to the activation of $\mathrm{G}_{\mathrm{q}}$ proteins, which in turn stimulates the phosphoinositide-specific PLC induced hydrolysis of $\mathrm{PIP}_{2}$ to $\mathrm{IP}_{3}$ and diacylglycerol. ${ }^{22)} \mathrm{IP}_{3}$ causes $\mathrm{Ca}^{2+}$ release from intracellular stores by binding to its intracellular receptor. $^{23)}$ It is generally accepted that platelets lack voltage-operated $\mathrm{Ca}^{2+}$ channels ${ }^{5)}$ and that various forms of receptor-mediated $\mathrm{Ca}^{2+}$ influx are activated by agonists. In our previous study, it was found that NQ-Y15 inhibits $\left[\mathrm{Ca}^{2+}\right]_{\mathrm{i}}$ elevation induced by AA. ${ }^{15)}$ This inhibition mechanism was investigated, referring to studies using U46619, a thromboxane mimic, in which both $\mathrm{Ca}^{2+}$ influx and its release from intracellular storage sites were found to contribute to the increase in $\left[\mathrm{Ca}^{2+}\right]_{\mathrm{i}}{ }^{24)}$ In the present study, we investigated whether NQY15 acts preferentially on $\mathrm{Ca}^{2+}$ influx from outer spaces or on its release from internal stores. As shown in Figs. 1B and 2B, NQ-Y15 significantly inhibited $\mathrm{Ca}^{2+}$ mobilization in AA-stimulated platelets through its inhibitory effects on both $\mathrm{Ca}^{2+}$ release from intracellular stores and $\mathrm{Ca}^{2+}$ influx. Inhibitory effects of NQ-Y15 on $\mathrm{Ca}^{2+}$ mobilization in AAstimulated platelets may be mainly due to the $\mathrm{TXA}_{2} / \mathrm{PGH}_{2}$ receptor blockade, which would decrease the formation of $\mathrm{IP}_{3}$.

The increase in $\left[\mathrm{Ca}^{2+}\right]_{\mathrm{i}}$ and platelet activation were not able to be fully inhibited by only suppressing the production or action of thromboxane. ${ }^{9,10)}$ While $\mathrm{TXA}_{2}$ synthase inhibitors or TXA $/ \mathrm{PGH}_{2}$ receptor antagonists alone do not affect the $\mathrm{Ca}^{2+}$ mobilization in AA stimulated platelets, dual acting drugs like picotamide, which act as $\mathrm{TXA}_{2}$ synthase inhibitors and as $\mathrm{TXA}_{2} / \mathrm{PGH}_{2}$ receptor antagonists, showed profound inhibitory effects on the increase of $\left[\mathrm{Ca}^{2+}\right]_{i}$ after stimulation with AA (Fig. 3B). It would be explained by the action of cAMP increasing during the metabolism of AA. ${ }^{13)}$ cAMP serves as a second messenger to inhibit the increase in $\left[\mathrm{Ca}^{2+}\right]_{\mathrm{i}}{ }^{11,12)}$ Adenylate cyclase forms cAMP from ATP. The activity of adenylate cyclase is regulated by $\mathrm{G}$ protein; it is stimulated by $G_{s}$ and inhibited by $G_{i}$. $G_{s}$ is coupled to the receptors for the inhibitory PGs, such as $\mathrm{PGD}_{2}$ and prostagladin $\mathrm{I}_{2}\left(\mathrm{PGI}_{2}\right) .{ }^{25)}$ It has been demonstrated that the $\mathrm{TXA}_{2}$ receptor is also coupled, in addition to the $\mathrm{G}_{\mathrm{q}}$ activating PLC, to $\mathrm{G}_{\mathrm{i} 2}$, which inhibits adenylate cyclase. ${ }^{26)}$ The combination of a $\mathrm{TXA}_{2}$ synthase inhibitory activity with a $\mathrm{TXA}_{2}$ receptor antagonistic action may lead to an increase in cAMP levels in AA-activated platelets. ${ }^{910)}$ To investigate whether the inhibitory effect of NQ-Y15 on $\mathrm{Ca}^{2+}$ mobilization was attributable to cAMP, we examined the effects of NQ-Y15 on the cAMP level in AA-stimulated platelets. As shown in Fig. 3B, NQ-Y15 increased the cAMP level in AAstimulated platelets.

We found that NQ-Y15 enhanced the $\mathrm{PGD}_{2}$ production in AA-stimulated platelets (data not shown). $\mathrm{PGD}_{2}$ was known to inhibit aggregation induced by ADP or collagen in human platelets but not in rat platelets. ${ }^{27)}$ Thus, we examined the effect of $\mathrm{PGD}_{2}$ on $\mathrm{Ca}^{2+}$ mobilization induced by AA or ADP and found that $\mathrm{PGD}_{2}$ does not inhibit the increase of $\left[\mathrm{Ca}^{2+}\right]_{\mathrm{i}}$ in rat platelets (data not shown). Vargaftig and Chignard (1975) reported that $\mathrm{PGE}_{1}$ and $\mathrm{PGF}_{2 \alpha}$ have anti-platelet aggregation-effects, but $\mathrm{PGE}_{2}$, shows the inhibitory effect on platelet aggregation induced by AA at the concentrations of more than $2 \mu \mathrm{m}{ }^{28)}$ Considering the fact that the amounts of prostagladins, other than $\mathrm{PGD}_{2}$, required to inhibit platelet activation are higher than those produced in the platelet, they might play a minor role in $\mathrm{Ca}^{2+}$ regulation. Sage and Heemskerk (1992) reported that thromboxane receptor stim- 
ulation inhibits adenylate cyclase and reduces cAMP-mediated inhibition of ADP-stimulated platelets. ${ }^{29)}$ Their results imply that blockade of the $\mathrm{TXA}_{2}$ receptor may activate adenylate cyclase by inhibiting the stimuli induced by thromboxane of the basal level or by $\mathrm{PGH}_{2}$ accumulated due to the inhibition of thromboxane synthesis. Judging from the previous reports and our experimental results, it was suggested that enhancement of cAMP might be due to both the adenylate cyclase stimulation and the antagonism of the adenylate cyclase inhibition by accumulated $\mathrm{PGH}_{2}$ or residual $\mathrm{TXA}_{2}{ }^{9}{ }^{9,10,30)}$ It was reconfirmed in this experiment that $\mathrm{PGD}_{2}$ produced by $\mathrm{TXA}_{2}$ inhibition could not directly increase $\left[\mathrm{Ca}^{2+}\right]_{\mathrm{i}}$ in rat platelets. Therefore, adenylate cyclase activation may play a more prominent role in AA-stimulated rat platelets, and prostaglandins other than $\mathrm{PGD}_{2}$ are probably responsible for the elevation of cAMP.

The increase in cAMP concentration leads to the reduced $\mathrm{IP}_{3}$ formation, ${ }^{31)}$ which stimulates $\mathrm{Ca}^{2+}$ influx and $\mathrm{Ca}^{2+}$ release from intracellular storage sites. ${ }^{32)}$ The elevation of cAMP concentration causes the activation of PKA, which in turn phosphorylates a number of substrates. Proteins phosphorylated by PKA include glycoprotein $\mathrm{Ib} \beta$ (a thrombin binding site), myosin light chain and actin binding protein (involved in platelet contraction), a $22 \mathrm{kDa}$ protein regulating the activity of a PLC (possibly rap 1B). ${ }^{33,34)}$ These facts suggest that NQ-Y15 might increase the cAMP level in stimulated platelets, which acts as an important inhibitory signal for $\mathrm{Ca}^{2+}$ mobilization.

In summary, NQ-Y15 was found to inhibit the increase of $\left[\mathrm{Ca}^{2+}\right]_{\mathrm{i}}$ in AA-stimulated rat platelets through the inhibition of calcium release from intracellular storage sites and $\mathrm{Ca}^{2+}$ influx. And this inhibition of $\mathrm{Ca}^{2+}$ mobilization might be caused by the elevation of cAMP, which contributes to the inhibition of platelet aggregation.

Acknowledgements This study was supported by grants from the ' 96 Good Health R\&D project, Ministry of Health \& Welfare, R.O.K (HMP-96-D-5-1045) and supported in part by the year (1999-2000) BK21 project for Medicine, Dentistry and Pharmacy and Research Institute of Pharmaceutical Sciences, College of Pharmacy, Seoul National University.

\section{REFERENCES}

1) FitzGerald G. A., Am. J. Cardiol., 68, 11B-15B (1991).

2) Parise L. V., Venton D. L., Le Breton G. C., J. Pharmacol. Exp. Ther., 228, 240-244 (1984).

3) Siess W., Siegel F. L., Lapetina E. G., J. Biol. Chem., 258, 1123611242 (1983).
4) Brass L. F., Shaller C. C., Belmonte E. J., J. Clin. Invest., 79, 12691275 (1987).

5) Rink T. J., Sage S. O., Annu. Rev. Physiol., 52, 431- 449 (1990).

6) Mayeux P. R., Morton H. E., Gillard J., Lord A., Morinelli T. A., Boehm A., Mais D. E., Halushka P. V., Biochem. Biophys. Res. Commun., 157, 733-739 (1988).

7) Gresele P., Deckmyn H., Nenci G. G., Vermylen J., Trends. Pharmacol. Sci., 12, 158-163 (1991).

8) Gresele P., Van Houtte E., Arnout J., Deckmyn H., Vermylen J., Thromb. Haemost., 52, 364 (1984).

9) Gresele P., Arnout J., Deckmyn H., Huybrechts E., Pieters G., Vermylen J., J. Clin. Invest., 80, 1435-1445 (1987).

10) Watts I. S., Wharton K. A., White B. P., Lumley P., Br. J. Pharmacol., 102, 497-505 (1991).

11) Feinstein M. B., Egan J. J., Sha'afi R. I., White J., Biochem. Biophys. Res. Commun., 113, 598-604 (1983).

12) Yamanishi J., Kawahara Y., Fukuzaki H., Thromb. Res., 32, 183-188 (1983).

13) Gresele P., Deckmyn H., Arnout J., Nenci G. G., Vermylen J., Thromb. Haemost., 61, 479-484 (1989).

14) Hoet B., Falcon C., De Reys S., Arnout J., Deckmyn H., Vermylen J., Blood, 75, 646-653 (1990).

15) Chang T. S., Kim H. M., Lee K. S., Khil L. Y., Ma W. C., Ryu C. K., Moon C. K., Biochem. Pharmacol., 54, 259-268 (1997).

16) Ryu C. K., Yakhak Hoeji, 32, 245-250 (1988).

17) Pollock W. K., Rink T. J., Biochem. Biophys. Res. Commun., 139, 308-314 (1986).

18) Grynkiewicz G., Poenie M., Tsien R. Y., J. Biol. Chem., 260, 34403450 (1985).

19) Karniguian A., Legrand Y. J., Caen J. P., Prostaglandins, 23, 437-457 (1982).

20) Magocsi M., Sarkadi B., Kovacs T., Gardos G., Biochim. Biophys. Acta, 984, 88-96 (1989).

21) Hashimoto Y., Ogihara A., Nakanishi S., Matsuda Y., Kurokawa K., Nonomura Y., J. Biol. Chem., 267, 17078-17081 (1992).

22) Baldassare J. J., Tarver A. P., Henderson P. A., Mackin W. M., Sahagan B., Fisher G. J., Biochem J., 291 (Pt 1), 235-240 (1993).

23) Berridge M. J., Irvine R. F., Nature (London), 341, 197—205 (1989).

24) Yun J. C., Ohman K. P., Gill J. R., Jr., Keiser H., Can. J. Physiol. Pharmacol., 69, 599-604 (1991).

25) Blockmans D., Deckmyn H., Vermylen J., Blood. Rev., 9, 143-156 (1995).

26) Ushikubi F., Nakamura K., Narumiya S., Mol. Pharmacol., 46, 808816 (1994).

27) Smith J. B., Silver M. J., Carol M. Ingerman, James J. Kocsis, Thromb. Res., 5, 291-299 (1974).

28) Vargaftig B., Chignard M., Agents Action, 5, 137-144.

29) Sage S. O., Heemskerk J. W., FEBS Lett., 298, 199-202 (1992).

30) Avdonin P. V., Svitina-Ulitina I. V., Leytin V. L., Tkachuk V. A., Thromb. Res., 40, 101-112 (1985).

31) Tohmatsu T., Hattori H., Nagao S., Ohki K., Nozawa Y., Biochem. Biophys. Res. Commun., 134, 868-875 (1986).

32) Kaser-Glanzmann R., Gerber E., Luscher E. F., Biochim. Biophys. Acta, 558, 344-347 (1979).

33) Brass L. F., Hoxie J. A., Manning D. R., Thromb. Haemost., 70, 217223 (1993).

34) Torti M., Lapetina E. G., Proc. Natl. Acad. Sci. U.S.A., 89, 77967800 (1992). 